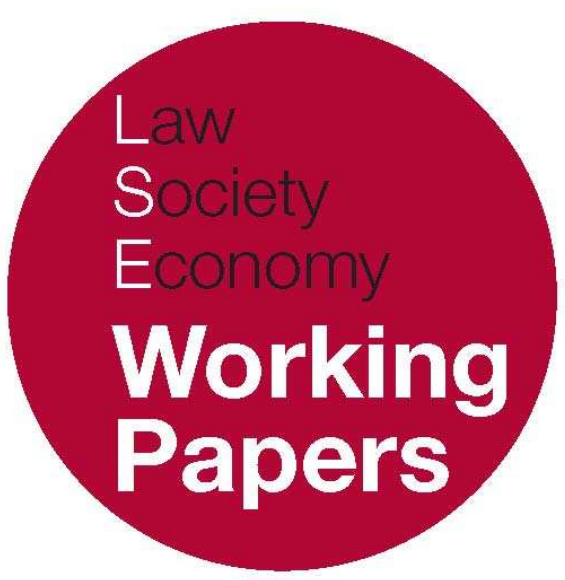

\title{
Why Is it Wrong to Breach an ASBO?
}

\author{
Peter Ramsay
}

LSE Law, Society and Economy Working Papers 20/2009

London School of Economics and Political Science

Law Department

This paper can be downloaded without charge from LSE Law, Society and Economy Working Papers at: www.lse.ac.uk/collections/law/wps/wps.htm and the Social Sciences Research Network electronic library at: http://ssrn.com/abstract=1491611.

(C) Peter Ramsay. Users may download and/or print one copy to facilitate their private study or for non-commercial research. Users may not engage in further distribution of this material or use it for any profit-making activities or any other form of commercial gain. 


\title{
Why Is it Wrong to Breach an ASBO?
}

\author{
Peter Ramsay*
}

\begin{abstract}
This article reviews the case law on the offence of breach of an ASBO and offers a theory of the public wrong identified by the courts as the reason for punishing people who commit the offence. It argues that the wrong that unifies all breaches of an ASBO is the insecurity caused by defendants' failure to address their disposition to cause insecurity in others. The greater is the insecurity that they are thought to have caused as a consequence of their failure, the more serious is the wrong and the more severe is the sentence to which they are liable. It is argued that this public protection theory gives a better account of the positive law than two competing accounts, namely the theory that the offence is simple defiance of the court's authority and the theory that breach of an ASBO is a 'composite offence' intended to aggregate many minor wrongs for the purposes of sentencing. Some of the problems and questions raised by the public protection rationale for punishment are briefly considered.
\end{abstract}

\section{INTRODUCTION}

It is a criminal offence for a person subject to an anti-social behaviour order (ASBO) to do anything that the order prohibits unless that person can prove a reasonable excuse for doing it. The maximum punishment is five years' imprisonment. ${ }^{1}$ This paper explains why the courts believe it is wrong to breach an

\footnotetext{
* Law Department, London School of Economics and Political Science. This paper is adapted from a draft of a chapter in P Ramsay, The Insecurity State: Criminal Law After the ASBO (Oxford: Oxford University Press, forthcoming). I am grateful to Andrew Ashworth, Lindsay Farmer, David Kershaw, Nicola Lacey, Stuart Macdonald, Alan Norrie, and an anonymous reviewer for OUP for their comments on and corrections to earlier drafts. The opinions and errors are all my own.

${ }^{1}$ Crime and Disorder Act 1998, s 1(10).
} 
ASBO. Or, to put it more precisely, the paper identifies the wrong for which a person who breaches an ASBO is lawfully punished.

At first sight, the answer may appear to be obvious: it is wrong to breach an ASBO because the breach is in defiance of a court order. Some commentators have argued that if the rationale of punishment for breaching an ASBO is defiance of the court, then such defiance can never justify a penalty of five years' imprisonment. ${ }^{2}$ It therefore seems unlikely that simple defiance could be the rationale, especially since the law already has penalties for contempt of court. The maximum sentence is two years, ${ }^{3}$ and where the contempt concerns breach of a court order, no criminal conviction is involved. It seems clear that parliament in making breach of an ASBO a criminal offence, and giving it a maximum sentence of five years, thought that breach of an ASBO involved a more serious wrong than simple defiance of a court order. But what is that more serious wrong?

Others have sought to explain the offence by focusing not on the formal defiance of the order, but on the content of the breaching behaviour. An ASBO prohibition may be anything 'necessary for the purpose of protecting persons...from further anti-social acts by the defendant'. ${ }^{4}$ Since many such prohibitions will simply forbid whatever conduct of the defendant was deemed anti-social by the court imposing the order in the first place, the breaches will themselves be anti-social acts, and the offence will share its substantive content with the grounds for imposing the ASBO. The shared substantive content in the grounds and in many breaches of ASBO have led some to argue that the offence of breaching an ASBO is a 'composite offence' for which a person is given a 'composite sentence' reflecting the whole course of conduct, including the conduct for which the order was imposed and that which has culminated in the breach. ${ }^{5}$ However, not all ASBO prohibitions directly prohibit anti-social behaviour. Some prohibit conduct that creates the circumstances in which the defendant's ASB occurs. Punishment for breaching these latter prohibitions appears at first sight to fit the defiance rationale, but not the composite sentence theory.

We will look at these problems in detail in what follows. The puzzle of the wrong done by breaching an ASBO arises in part because of the novel form of the criminal offence, as a breach of a court order. Where more familiar criminal offences exist independently of any particular court's decision, breach of ASBO is wholly dependent on the existence of a court order. As a consequence, where more familiar criminal offences can potentially be committed by anyone who engages in the particular conduct prohibited by the offence, a breach of an ASBO can only be committed by the person subject to the order — the offence has no

\footnotetext{
2 See, A.P. Simester and A. von Hirsch, 'Regulating Offensive Conduct Through Two-Step Prohibitions' in A. von Hirsch and A.P. Simester (eds), Incivilities (Oxford: Hart, 2006), 188-189.

${ }^{3}$ Contempt of Court Act 1981, s 14(1).

4 Crime and Disorder Act 1998, s 1(6).

5 See, S. Macdonald, 'The Principle of Composite Sentencing: Its Centrality to, and Implications for, the ASBO’ (2006) Criminal Law Review 791.
} 
general application. The content of the offence is also different from more familiar criminal offences in one important respect. Where more familiar criminal offences prohibit relatively specifically defined wrongs (such as homicide, criminal damage, possession of a controlled substance), ${ }^{6}$ the statutory power to grant an ASBO gives only the thinnest description of the content of the conduct that may be prohibited: anything that is necessary to protect other people from further antisocial acts by the defendant. ${ }^{7}$

A further and very significant complication is that ASBO prohibitions that do directly prohibit anti-social behaviour (ASB) often overlap with the existing criminal law. Much criminal conduct is also anti-social according to the statutory definition of ASB (which we will consider in more detail shortly). As a result, ASBOs often prohibit conduct that would be a criminal offence even if there were no ASBO in place. How should sentencing for breaching an ASBO relate to sentencing for the ordinary criminal offence committed by means of the same conduct?

This paper analyses both the preventive content and the individualised form of the breach of ASBO offence. In both of these aspects, breach of ASBO presents some novel problems for the criminal courts. In grappling with these problems, the Court of Appeal has had to work out what wrong is done when an ASBO is breached. By looking at the court's answer to these problems, we will find that it is neither simple defiance nor composite sentence that gives an adequate account of the law of breach of ASBO. Rather, the offence is best understood as punishing the wrong of causing insecurity by a dispositional failure to respect the security interests of others.

The paper is limited to identifying and giving as coherent an account as possible of the wrong that is disclosed by the courts' interpretation of the offence. This paper does not address any philosophical issues concerning the rights and wrongs of the positive law. Some readers may object that they do not recognise the wrong identified in this paper as a wrong, or, that in some or even all cases, they regard it is as a wrong that is not appropriate for punishment. But the concern of the paper is not to justify the sentencing regime for breach of ASBO, but to lay bare how that regime is rationalised by parliament and the courts.

The paper, therefore, proceeds with an analysis of the case law on breach of ASBO. We will first set out the problem by categorising ASBO prohibitions in terms of different types of content. We will then set out the problem presented by the overlap with the ordinary criminal law and consider how both the content of the prohibitions and the individualised form of the offence have affected the courts' approach to sentencing breaches of ASBO that involve this overlap. On the basis of this analysis, the wrong that the law identifies when a breach of ASBO is committed will be outlined. We will conclude with a brief critique of the

\footnotetext{
6 There are many who would contest that the possession of controlled substances is wrong from a moral standpoint, but the law's statement of what is authoritatively determined to be wrong is relatively specific when compared with breach of an ASBO.

7 Crime and Disorder Act 1998, s 1(6).
} 
composite offence theory of breach of ASBO and outline the interesting questions raised by the theory offered here.

\section{THREE TYPES OF ASBO PROHIBITION}

An anti-social act is defined in Section 1(1) CDA 1998 as one that 'caused or was likely to cause harassment, alarm or distress to one or more persons not of the same household' as the person doing the act. At first glance, it might seem that, to satisfy Section 1(6)'s requirement that ASBO prohibitions be necessary to prevent further anti-social acts, all an ASBO needs to contain is a single generic prohibition of behaviour 'likely to cause harassment, alarm or distress to persons not of the same household'. But, while some such broad prohibition may be included in an ASBO, ${ }^{8}$ it is far from exhaustive of the preventive possibilities provided for by Section 1(6). Nor would it be sufficient to meet its requirements. The reason is that for a prohibition to be 'necessary', it must serve the aim of prevention, and as the Judicial Studies Board points out in its guidance on ASBOs, to serve this aim properly: '[E]ach separate prohibition must be targeted at the individual and the specific form of anti-social behaviour it is intended to prevent. The order must be tailored to the defendant and not designed on a word processor for generic use. ${ }^{\prime 9}$

Moreover, to be necessary for prevention, each prohibition must be precise and capable of being understood by the defendant. The Judicial Studies Board adds that 'the court should ask itself before making an order, "Are the terms of this order clear so that the defendant will know precisely what it is that he is prohibited from doing?"”. ${ }^{10}$ In general, therefore, ASBO terms need to be specific and precise prohibitions on the conduct that is involved in the particular defendant's past anti-social behaviour — the behaviour that the order is intended to prevent in future. This allows for a wide scope of possible prohibitions, which has posed some interesting problems for the courts. Two are of particular interest for present purposes.

The first arises because there is no requirement that a term in an ASBO prohibits conduct that in itself causes harassment, alarm or distress. If, for example, a particular defendant causes harassment, alarm or distress in a particular neighbourhood, then prohibiting her from that neighbourhood may be necessary to prevent future ASB. This prohibition may be necessary notwithstanding the fact that the defendant does not cause harassment, alarm or distress most of the time that she is present in the neighbourhood. Such movement restrictions are commonly included in ASBOs. Along with terms such as prohibitions on

\footnotetext{
${ }^{8}$ Subject to the strictures in CPS v T (Michael) [2006] EWHC 728 (Admin).

9 Judicial Studies Board, Anti-Social Behaviour Orders: A Guide for the Judiciary (London: Judicial Studies Board, 2007), 16

10 ibid.
} 
associating with named individuals, drinking alcohol, curfews, and so on, such prohibitions can for present purposes be called purely preventive prohibitions. The problem they pose is that if these prohibitions are violated, the defendant has committed an offence with a maximum penalty of five years' imprisonment, although in the particular circumstances she may have done something that, but for the order, would not be unlawful, and, since it need not even involve the causing of harassment, alarm or distress, might not even be wrongful or harmful in any way. What is the justification for punishing someone in these circumstances, and what should their sentence be?

But ASBO terms are not restricted to purely preventive prohibitions. If a defendant causes harassment, alarm or distress by, say, regularly spitting and kicking footballs at other people's property, then prohibiting him from spitting and from kicking footballs at others' property might be necessary prohibitions. ${ }^{11}$ Moreover, this second category of ASBO terms, those that prohibit conduct that directly causes harassment, alarm or distress, can itself be broken down into two sub-categories: those that prohibit conduct that is not a criminal offence (like spitting or kicking footballs) and those that prohibit conduct that is already a criminal offence (like assault, criminal damage, public order offences, drugs offences, and many others). Much criminal conduct will also cause harassment, alarm or distress. Prohibitions on already criminal conduct are particularly prominent because ASBOs are widely used as a response to conduct that would give rise to the possibility of criminal prosecution, at least in theory, ${ }^{12}$ or are imposed, under Section 1C Crime and Disorder Act 1998, on a person who has been convicted of a criminal offence (a so-called CrASBO). ${ }^{13}$ For present purposes, we will refer to these prohibitions as 'criminal terms', and they pose the second set of problems for the courts.

The problem posed by criminal ASBO terms is in what circumstances can it be 'necessary' to prohibit by means of an ASBO conduct that is already a criminal offence? Why is the ordinary criminal law not sufficient for the purpose? This overlap between the ASBO and the rest of the criminal law has raised a further related problem in sentencing decisions. Where a defendant's conduct both breaches an ASBO and amounts to a criminal offence, with a maximum sentence that is less than five years, can the sentence be higher than the maximum for the ordinary offence?

We therefore need to identify how the courts have explained the necessity of criminal terms, how higher sentences for breach of ASBO than for standalone

\footnotetext{
${ }^{11}$ Hills v Chief Constable of Essex [2006] EWHC 2633.

${ }^{12}$ The original policy motive for the ASBO was to permit the control of criminal nuisances, which taken in isolation, were too minor to justify prosecution, but when considered in aggregate, amounted to more serious criminality. See, Labour Party, A Quiet Life: Tough Action on Criminal Neighbours (London: Labour Party, 1995).

${ }^{13}$ For a review of the precise procedures to be followed, see, $R \mathrm{v} W$ and $F[2006] 2 \mathrm{Cr}$ App R (S) 110. On the prevalence of CrASBOs, see, R. Matthews, H. Easton, D. Briggs, and K. Pease, Assessing the Use and Impact of Anti-Social Behaviour Orders (Bristol: Policy Press, 2007), 18-20; E. Burney, No Spitting: Regulation of Offensive Behaviour in England and Wales' in A. von Hirsch and A. Simester (eds), Incivilities (Oxford: Hart, 2006), 214.
} 
criminal offences might be justified, and whether this justification of punishing breach of ASBO terms can be made to cohere with punishing purely preventive terms on occasions where no harassment, alarm or distress is caused.

\section{THE PROBLEM OF CRIMINAL ASBO TERMS}

The Court of Appeal has ruled that criminal ASBO terms cannot be imposed merely to increase the sentence for the criminal offence. In Kirby, a CrASBO was imposed which only prohibited the defendant from conduct which amounted to the offences of taking vehicles without the owner's consent and driving while disqualified. In explaining the reason for, and the effect of, the order, the sentencing judge had said to the appellant that the ASBO 'actually increases the penalty that the courts can impose on you for those offences, which are now, maximum 6 months. It increases the penalty to five years. ${ }^{14}$ The Court of Appeal quashed the ASBO on the grounds that the judge's words made plain that the order had been imposed simply to increase the available sentence and not to prevent further ASB by the defendant.

In Morrison, the Court of Appeal reaffirmed the logic of Kirby in an appeal against sentence for breach of a criminal ASBO term. ${ }^{15}$ The defendant was arrested after driving a car in breach of an ASBO term prohibiting him from being in the front seat of a car. He was also disqualified from driving at the time. He was convicted of breach of ASBO and sentenced to 12 months' imprisonment. Justice Hughes upheld his appeal against sentence substituting a sentence of six months on the grounds that it was not open to the court to 'evade' the maximum sentence set by parliament by imposing an ASBO simply to increase the sentence for further offences. ${ }^{16} \mathrm{He}$ then went on to suggest that:

If a breach of an ASBO consists of no more than the commission of an offence for which a maximum penalty is prescribed by statute, it is wrong in principle to pass a sentence for that breach, calculated by reference to the five-year maximum for breach of an ASBO...We draw attention however in that last proposition to the words "no more than". There may be exceptional circumstances in which it can properly be said that the vice of breach of an ASBO although it amounts to an offence, goes beyond that offence. ${ }^{17}$

Where the Morrison court doubted that there would often be a justification for imposing higher sentences for criminal ASBO terms than were available for the equivalent criminal offence, in Boness, a few months later, the Court of Appeal cast

${ }^{14}$ R v Kirby [2005] EWCA Crim 1228 at [6].

${ }^{15} \mathrm{R}$ v Morrison [2006] $1 \mathrm{Cr}$ App R (S) 85.

16 ibid at [18].

17 ibid at [19]. 
doubt on whether such terms could be justified in the first place. Drawing attention to the words of section 1(6), the court ruled that the test for inclusion of any prohibition in an ASBO was that it must be necessary to prevent further antisocial behaviour by the defendant. ${ }^{18}$ On this basis, Lord Justice Hooper reaffirmed the logic of Kirby that criminal terms could not be included merely to increase the sentence for an offence where the maximum was thought too lenient. Although Morrison was not referred to in Boness, Lord Justice Hooper nevertheless also thought that the circumstances in which a criminal term might be necessary would be exceptional:

It follows from the requirement that the order must be necessary to protect persons from further anti-social acts by him, that the court should not impose an order which prohibits an offender from committing a specified criminal offence if the sentence which could be passed following conviction for the offence should be a sufficient deterrent. If following conviction for the offence the offender would be liable to imprisonment then an ASBO would add nothing other than to increase the sentence if the sentence for the offence is less than five years' imprisonment. But if the offender is not going to be deterred from committing the offence by a sentence of imprisonment for that offence, the ASBO is not likely (it may be thought) further to deter and is therefore not necessary. ${ }^{19}$

Combining these arguments from Boness and Morrison poses the key question: how can criminal terms be necessary if the sentence for breach cannot be higher than the maximum for the criminal offence?

In Boness, Lord Justice Hooper took the view that since 'the aim of an ASBO is to prevent anti-social behaviour....the police or other authorities need to be able to take action before the anti-social behaviour it is designed to prevent takes place.... ${ }^{20}$ In consequence, he thought only purely preventive terms are likely to be appropriate. But Lord Justice Hooper's suggestion has not been followed because, when his judgement in Boness is read together with that in Morrison, the possibility of criminal terms remains open. In Boness, Lord Justice Hooper's argument was that adding the criminal ASBO term could not be 'necessary' because it would add nothing to the effect of the existing criminal offence. But in Morrison, Justice Hughes was careful to recognise that there might exist 'exceptional circumstances' in which the breach of the ASBO term amounted to 'more than' the criminal offence, justifying a higher sentence. In such circumstances, a criminal term might conceivably add something and be rendered 'necessary'.

In Stevens, the Court of Appeal affirmed that the offence of breach of ASBO should be regarded as separate from the criminal offence that may also be committed when the order is disobeyed. The defendant had breached an ASBO

${ }^{18} \mathrm{R}$ v Boness [2005] All ER (D) 153 at [31].

19 ibid at [30].

$20 \mathrm{ibid}$ at [35]-[36]. 
prohibiting him from being drunk or urinating in a public place. ${ }^{21} \mathrm{He}$ had 135 previous convictions for public drunkenness and other minor offences. The judge sentenced him to nine months' imprisonment for the breach. Stevens appealed sentence on the grounds that the maximum for being drunk in a public place was a fine. Lord Justice Judge ruled that:

It cannot...be right that the court's power is...limited to the...maximum imprisonment of the distinct criminal offence. That would treat the breach as if it were a stand-alone offence, which at the time when it was committed did not amount to a breach of the court order. In reality, the breach is a distinct offence in its own right, created by statute, punishable by up to five years' imprisonment. ${ }^{22}$

By clearly separating the different offences disclosed by the same conduct, one a specific criminal wrong of being drunk in a public place, the other the breaching of an ASBO, Lord Justice Judge gives a formal explanation as to why a higher sentence for breach of a criminal ASBO term than for the stand-alone offence is possible. The separate offence means that some wrong in addition to the ordinary criminal wrong is being committed, and a higher sentence may be justified. In other words, in some circumstances, the offence of breaching the criminal ASBO term must be 'adding something' to the ordinary criminal law, contrary to Lord Justice Hooper's expectations in Boness. But what is that 'something' that the criminal term can be said to be 'adding'?

\section{A 'PUBLIC PROTECTION' OFFENCE}

In Stevens, the court upheld the reasoning in Lamb and Braxton with respect to the sanctions for breach of a criminal term, and disapproved of Morrison. In Lamb, Leveson J had criticised the Morrison approach - ie, ruling out higher sentences for breach of ASBO than the maximum available for the stand-alone offence - on the grounds that it 'appears to ignore the impact of anti-social behaviour on the wider public which was the purpose of the legislation in the first place'. ${ }^{23}$ It is the harassment, alarm or distress caused by the defendant who breaches an ASBO which is the something 'more than' the equivalent criminal offence and which justifies the higher sentence. On the facts of Morrison, the defendant's breach of his ASBO did not cause any harassment, alarm or distress and therefore did not amount to anything more than the offence of driving while disqualified. But the problem with the Morrison judgement is that the court describes as 'exceptional

${ }^{21} \mathrm{R}$ v Stevens, R v H [2006] 2 Cr App R (S) 453.

22 ibid at [26]-[27] (emphasis added).

${ }^{23} \mathrm{R} v$ Lamb [2005] All ER (D) 132 at [16] 
circumstances' precisely those at which the ASBO legislation is primarily aimed circumstances in which the defendant is likely to cause harassment, alarm or distress. ${ }^{24}$

Leveson $\mathrm{J}$ in Lamb cited the earlier case of Braxton in which the Court of Appeal refused leave to appeal against a sentence of three and a half years on the defendant, who had repeatedly breached an ASBO soon after release on licence from a prison sentence for an earlier breach of the same ASBO. In that case, the court made explicit reference to the legislation being parliament's response 'to increasing concerns about the impact on the public of anti-social behaviour in its many forms'. ${ }^{25}$ The maximum sentence of five years therefore marks the potential seriousness of the ASB that a defendant might cause, and it is the seriousness of the ASB caused by a defendant that should be the issue in sentencing. ${ }^{26}$

It is the seriousness of conduct in terms of the harassment, alarm or distress involved in breach of a criminal ASBO term that makes a higher sentence possible. The higher sentence is justified as proportional to the greater wrong caused to others by the harassment, alarm or distress in addition to the specific wrong of the ordinary criminal offence, and, arguably, in the preventive context of section 1(6) because its availability provides greater deterrence of the greater wrong.

The case of Harris provides a striking example of this rationale. ${ }^{27}$ The defendant masturbated in front of three 12-year old girls at a bus stop and asked them if they wanted to touch his penis. He pleaded guilty to two counts of engaging in sexual activity in the presence of a child and was sentenced to 18 months' concurrent imprisonment for each of those offences. He also pleaded guilty to breach of an ASBO imposed a year earlier, prohibiting him from associating with girls under 16, for which he was sentenced to four years - also to run concurrently. On appeal against the sentence for breach of the ASBO, Lord Justice Kay relied on the distinction between the two offences made in Stevens and upheld the imposition of the maximum sentence for the breach on the grounds that: We...detect no lack of proportionality between a sentence of four years and the criminality engaged in on this occasion in the form of the breach of the ASBO. ${ }^{28}$ Kay LJ mentions as aggravating factors the defendant's 18 previous offences and lack of remorse. The maximum sentence is upheld, and this sentence

\footnotetext{
24 The Lamb court pointed out that if courts were forced 'in principle' never to sentence for breach of a criminal term in excess of the statutory maximum, this would mean 'that antisocial behaviour short of a criminal offence could be more heavily punished than antisocial behaviour that coincidentally was also a criminal offence' (ibid at [16]).

25 R v Braxton (No2) [2005] 1 Cr App R (S) 36 at [3].

26 See also, Sentencing Advisory Panel, 'Consultation Paper on Breach of Anti-Social Behaviour Orders' (London: Sentencing Advisory Panel, 2007), 18.

27 R v Harris [2006] All ER (D) 301.

$28 \mathrm{ibid}$ at [13]. In Harris' case, the maximum sentence included a discount to take account of the fact that he had pleaded guilty without delay. The sentencing court had reduced his term to four years, although the CA, with some reluctance, recognised that the proper discount for the guilty plea would reduce his sentence to 3 years and 3 months and substituted that sentence.
} 
is rather greater than the appropriate sentence for the fairly serious sexual offences disclosed on the facts.

Similarly, in Lawson, the Court of Appeal upheld a maximum six-month sentence for a serious common assault, while, for the breach of an ASBO term arising out of the same incident, the court substituted a 10-month concurrent sentence for the original sentence of 10 months to run consecutively. ${ }^{29}$ Lawson had six previous convictions, including two for public order offences and one for harassment. ${ }^{30}$ The effect of the sentence for breach of ASBO was nevertheless to increase the penalty for the assault by two-thirds to take account of the harassment, alarm or distress likely to be caused by the defendant's breach.

These cases suggest that the courts consider the offence of causing harassment, alarm or distress in breach of an ASBO to be at least as wrongful as quite serious assaults and sexual offences. From the Court of Appeal's point of view, parliament has supplied the courts with a sentencing power which reflects the need 'to protect' the public from this serious wrong. Of course it can be objected that there is no conclusive evidence for the marginal deterrence effect of the increased sentencing power, ${ }^{31}$ and, therefore, that criminal ASBO terms are not rendered necessary from the point of view of preventing further ASB. Moreover, a breach of ASBO conviction suggests that the higher sentence was not an effective deterrent in the particular case. But these objections have to be taken in the context of the peculiar individualised form of the offence of breach of ASBO

In any particular case, the conduct element of the offence of breach of ASBO will only exist as a consequence of its 'necessity' in order to protect the public from the particular defendant to whom it applies. If it was not deemed necessary to protect the public from the particular defendant, the ASBO term would not exist nor would the criminal offence. The very existence of the offence is dependent therefore on an assessment of the particular risk that the defendant is thought to represent - an assessment which is made in imposition proceedings which give rise to the ASBO with its particular terms..$^{32}$ It is plain from the statutory language that the control of the risk that the defendant represents is the raison d'etre of the offence. Where a defendant goes on to cause ASB in breach of an ASBO term, which is to say, in precisely the form which she has been warned by the courts not to, her actions can be thought of as having proved the risk assessment correct. The protection of the public from the particular individual, which was the rationale for the imposition of the ASBO term, then becomes the rationale for the

${ }^{29} \mathrm{R} v$ Lawson [2007] All ER (D) 61.

30 ibid at [6].

31 See, A. von Hirsch, A. Bottoms, E. Burney and P-O. Wikstrom, Criminal Deterrence and Sentence Severity:

An Analysis of Recent Research (Oxford: Hart, 1999), 47-48.

32 See, P. Ramsay, 'What is Anti-Social Behaviour?' (2004) Criminal Law Review 908. 
sentence. ${ }^{33}$ Where that breach involves conduct that is also a criminal offence, the ASB caused is more likely to be serious and attract a more severe sentence. ${ }^{34}$

When the judges recall the depressing history of Stevens' drunkenness, Harris' masturbating, or Lawson's loutishness, they are making reference to the special risk that the imposition of the breached ASBO term had constructed them as representing in the first place - a special risk which, when it subsequently materialises in the breach of the ASBO, justifies a sentence for public protection. This reasoning is made explicit in the case of Anthony. The defendant was an alcoholic with a long history of drunken assaults and racial abuse against hospital staff. She had previously been imprisoned for various offences and had breached previous ASBOs on eight occasions. She was prohibited by an ASBO from abusing NHS staff or being drunk in a public place. The day after the order was imposed, she got drunk and assaulted hospital staff. At trial, the judge imposed a maximum sentence for the single breach on the explicit grounds that hospital staff needed protection from the defendant. The judge had before her a pre-sentence report which, in the words of the Court of Appeal, indicated that 'every possible community penalty had been explored in order to engage the appellant, but nothing had effected any lasting change. She was unwilling or unable to comply with the [probation] service'. ${ }^{35}$ The Court of Appeal upheld the sentence in principle on the grounds that the defendant is just the sort of offender that antisocial behaviour orders were devised to control and as yet they are proving singularly ineffective....We fully understand why the judge passed what she intended to be a long sentence. ${ }^{36}$

Imposition of the ASBO constructed Anthony as a special risk of the prohibited ASB-causing behaviour. Protecting the public by preventing further anti-social acts by her required the greater deterrence of breach of ASBO, and, when even that failed, incapacitation by incarceration. The critical point is that by imposing the ASBO in its particular terms, the defendant has, in the words of Anesh Pema and Sharon Heels, 'been differentiated from other members of the public by reason of his past conduct'. ${ }^{37}$ In Anthony, that past conduct revealed a disposition to get drunk and harass NHS staff. This disposition made the order 'necessary' because greater powers of deterrence and incapacitation are needed to protect the public from this defendant in this respect. ${ }^{38}$

\footnotetext{
33 In addition to the cases considered below, this logic can be applied equally to Lawson, Harris, and Stevens, respectively, n 29, n 27, and n 21 above.

34 Although not necessarily, since the commission of some criminal offences may be such as to not cause harassment, alarm or distress or be likely to, only on some occasions and not others - for example, shoplifting - see generally, R (Mills) v Birmingham Magistrates Court [2005] All ER (D) 94.

${ }^{35} \mathrm{R} v$ Anthony [2006] I Cr App R (S) 74 at [8].

36 ibid at [12]. The connection between the defendant's past conduct and the need for protection of the public once an ASBO term is breached is equally explicit in Braxton (No2) (n 25 above); see, text at n 44 below.

37 A. Pema and S. Heels, Anti-Social Behaviour Orders (Bristol: Jordan, 2006), 108.

38 On the dispositional component of the necessity test in the grounds for imposing an ASBO, see, Ramsay, n 32 above.
} 
In Hills v Chief Constable of Essex, the respondent explicitly advanced this argument for the necessity of a criminal ASBO term as a form of special deterrence for the particular defendant. Keith J commented that, notwithstanding Lord Hooper's scepticism in Boness, 'these are powerful arguments', although on the facts of the case, he ruled that he did not have to decide the issue. ${ }^{39}$ They are powerful arguments because they draw out the logic of risk management found in the terms of Section $1 \mathrm{CDA}$. Those people for whom specific prohibitions are 'necessary' to prevent them from causing 'harassment, alarm or distress' have indeed been differentiated from other citizens for whom such specific prohibitions are not necessary. The imposition of a criminal ASBO term, with its higher maximum sentence, is based on the assessment that the defendant represents a special risk of causing harassment, alarm or distress in the form of the conduct concerned. Indeed, any ASBO term which was not based on such an assessment would be open to legal challenge. 40

It is important to note that this rationale is not in violation of the rule in Kirby from which we set out. This is not an argument for merely increasing the sentencing power because the maximum for that criminal offence is thought inadequate. The increased sentencing power is to protect the public from the ASB which the particular defendant has a propensity to cause, rather than from the wrong prohibited by the specified criminal offence.

In respect of breach of criminal ASBO terms, and by implication of any term where harassment, alarm or distress is caused, breach of ASBO is an offence of public protection - protection from the risk of harassment, alarm or distress that the particular defendant has been authoritatively determined to represent by the imposition of the ASBO. In other words, it is the risk of insecurity that the defendant represents that is at the core of the offence of breach of ASBO. ${ }^{41}$ The wrong of breaching an ASBO is the threat that is involved in maintaining a disposition to cause harassment, alarm or distress. The more serious the threat posed by the breach, the more serious the wrong done by the offence and the higher the proportionate sentence.

This theory of the wrong done by breaching an ASBO has the advantage that it can account for the Court of Appeal's approach to breaches of purely preventive terms where no harassment, alarm or distress is caused directly by the breaching conduct itself. In Lamb, the defendant had been sentenced to 22 months for repeated breaches of an ASBO term prohibiting him from being anywhere on the

\footnotetext{
39 See, Hills v Chief Constable of Essex [2006] All ER (D) 35 (Oct) QBD at [14]-[16].

${ }^{40}$ See, $R \mathrm{v}$ Jones and Others [2006] All ER (D) 97 (Sep) CA.

41 Some writers have assumed that 'harassment, alarm or distress' can be equated with offensiveness: see, various contributions to von Hirsch and Simester, n 2 above. I have elsewhere argued that in the context of the ASBO, conduct likely to cause harassment, alarm or distress is better understood as conduct that manifests a disposition of indifference or hostility to the security needs of others: see, P. Ramsay, 'The Theory of Vulnerable Autonomy and the Legitimacy of the Civil Preventative Order' (LSE Law, Society and Economy Working Paper Series no. 01/2008, 2008); published in B. McSherry, A. Norrie, and S. Bronitt (eds), Regulating Deviance: Redirection of Criminalisation and the Futures of Criminal Law (Oxford: Hart, 2009), 109-140.
} 
Tyneside Metro system. The breaches did not involve the causing of any harassment, alarm or distress, and the Court of Appeal reduced Lamb's sentence to eight months, ruling that where no harassment, alarm or distress was occasioned by the breach, a community penalty was to be preferred, but that the authority of the order was important, so in respect of repeated breaches, 'custodial sentences which are necessary to maintain the authority of the court can be kept as short as possible'. ${ }^{42}$

In Lamb, the Court of Appeal speaks in terms of maintaining the authority of the court. But a defendant's simple defiance of the judicial authority, in the context of the order's preventive aims, itself manifests the threat that the defendant has been constructed as representing. Although no harassment, alarm or distress may be caused on the occasion of a breach, the breach itself, especially if it is a repeated breach, suggests that the defendant is willing to breach the order or at least not willing to take sufficient care to avoid breaching it and, therefore, continues to manifest the particular risk of harassment, alarm or distress materialisation of which the order is intended to prevent. The simple defiance of the court's authority itself manifests a degree of risk with respect to others' security, albeit in a less serious form. In other words, sentence for breach of a purely preventive term can be justified by the same rationale as sentence for a breach that directly causes harassment, alarm or distress.

Any doubts about the public protection theory of breach of ASBO should be settled by the Court of Appeal's review in $R$ v Fenton of several of the cases discussed here. The court sought to ascertain the breach of ASBO sentencing principles and apply them to the offence of breach of a Sex Offender Order. The Court understood the crucial factor in sentencing to be the degree of risk to the public represented by the breach: the greater the risk to the public which a breach 'involves' or 'creates', the higher the sentence. Where a sufficiently high risk is disclosed by the breach, sentences higher than those available for the specific criminal offence which might have been prosecuted will be justified.43

\section{WHY IT IS WRONG TO BREACH AN ASBO}

Understanding the sentence as proportionate to the threat which the particular defendant represents allows us to explain breaches that cause harassment, alarm or distress and breaches of purely preventive obligation without causing harassment, alarm or distress as a single wrong. Each time the offence comes into existence, by virtue of the imposition of an ASBO, it legally defines the defendant as a particular and clearly specified threat of harassment, alarm or distress. Obedience to the order will avoid any manifestation of the specific threat. It appears then that it is

\footnotetext{
42 n 23 above at [19].

43 See, R v Fenton [2007] 1 Cr. App. R. (S.) 97 at [25].
} 
wrong to breach the ASBO because the breach is a failure by the defendant to take seriously the threat of harassment, alarm or distress caused to others that the ASBO authoritatively constructs the defendant as representing. This is not the same as simple defiance of the order, which in itself is just one relatively mild form of this failure, as Lamb makes clear, nor is it simply the content of the conduct on any particular occasion. It is the conduct in the context of the reasons for the order. In Braxton (No2), the court put it like this:

[T] he applicant still does not appear to understand the nature or effect of the order made against him. The anti-social behaviour order is specifically designed to protect the public from frequent and distressing repeated misbehaviour of the type which is the subject of this order....He acted in deliberate breach of that order not once but twice... and yet again twice more within weeks of his release from [a] prison sentence. He must understand that what he might consider as trivial in his case, because of the persistence of his conduct, is now treated seriously, specifically to protect the public. It is thus vital that he address this issue and his behaviour in public if he is to avoid further conflict with the law. ${ }^{44}$

It is the unreformed defendant, her unaddressed disposition to cause harassment, alarm and distress to others, and the continuing risk that she therefore constitutes and from which the public requires protection, that constitute the wrong targeted by breach of ASBO. When the defendant breaches the ASBO, she demonstrates her contempt or indifference to the obligations it contains, and these obligations are to desist from manifesting the threat to others' security. When this indifference or contempt is manifested in ways that cause harassment, alarm or distress in a form that the courts have specifically prohibited, the wrong is regarded as grave. The breaching conduct itself is important, but as the manifestation of the continuing risk represented by the defendant.

The wrong in breach of ASBO is the failure to address the behaviour that causes insecurity to others when required to by the court. It is punished in proportion to the degree of threat made manifest in the breach. The proposition that this is the wrong involved in breaching an ASBO is reinforced by the offence being one of strict liability. If the ASBO defendant does anything that is prohibited by the order, the prosecution will not have to prove that she intended or knew there was a risk of the conduct; on the contrary, the ASBO defendant will have to prove that she has a reasonable excuse. ${ }^{45}$ In respect of this criminal liability, the defendant is required positively to address her propensity to cause harassment, alarm or distress by making sure she avoids the conduct which causes it. In the case of a criminal ASBO term, the contrast with the ordinary criminal law of mens rea (such as assaults, criminal damage, or sexual offences) is marked.

$44 \mathrm{n} 25$ above at [17].

${ }^{45}$ Crime and Disorder Act 1998, s 1(10). 
The burden of avoiding the prohibited conduct placed on the individual subject to an ASBO is greater than that placed on the ordinary citizen. The reason is that breach of ASBO offence concerns a different wrong from the ordinary criminal offence - the wrong of continuing to manifest a threat to the security of others in defiance of the official demand to desist.

This wrong is more than mere defiance of a court order; it is defiance that sets back the security interests of the persons the order was necessary to protect. This account incorporates the defiance-based rationale of breach of ASBO, but identifies a wrong going beyond mere defiance. That wrong is not, however, the same as the 'composite offence' that has been suggested in the literature, and to that theory we now briefly turn.

\section{THE ‘COMPOSITE OFFENCE’ THEORY}

Stuart Macdonald has offered a different theory of breach of ASBO. Under what he terms the 'principle of composite sentencing', the sentence imposed 'should reflect not just the seriousness of the act of breach, but rather the aggregate impact of the individual's entire course of conduct'. ${ }^{46}$ Macdonald's theory explains breach of ASBO as a composite offence - a means to aggregate many minor individual incidents for the purposes of punishment. Any ASBO terms are 'necessary' in so far as they put the defendant on notice that continuing with the course of conduct will render her liable for the composite offence with its composite sentence.

Macdonald finds support for this theory in Lord Justice Judge's conclusion in Stevens that the defendant's sentence of nine months was appropriate because 'Given the appellant's prolonged history of offending it would not be right for this Court to interfere with [the sentencing judge's] decision.'47 Macdonald interprets this conclusion to mean that the defendant was being punished for the entire course of conduct which had preceded the imposing of the ASBO as well as the breaches themselves. We have seen above that these words can also be read as providing the context for the assessment of the risk disclosed by the particular breach rather than part of an assessment of wrongful conduct to be aggregated. The aggregation theory is an improbable interpretation of the case law for the several reasons.

Macdonald derives his theory from the original motivation for the ASBO in the Labour Party document $A$ Quiet Life. In that document, the ASBO appeared in an earlier incarnation as the Community Safety Order. It was promoted as one means to prevent anti-social behaviour conceived of as a course of conduct in which the individual incidents might be too trivial to prosecute, but the aggregate

\footnotetext{
46 Macdonald, n 5 above, 800. See also, R. Hansen, L. Bill, and K. Pease, 'Nuisance Offenders: Scoping the Public Policy Problems' in M. Tonry (ed), Confronting Crime: Crime Policy Under New Labour (Cullompton: Willan, 2003).

${ }^{47} \mathrm{n} 21$ above at [29] (emphasis added).
} 
impact on its victims was nevertheless severe. ${ }^{48}$ It is the potential severity of this aggregate impact that, according to this argument, would account for the severe maximum sentence for breach. Macdonald argues that in Stevens, by upholding a sentence based on the defendant's prolonged history of minor offending which had led to the imposition of an ASBO in the first place, the Court of Appeal has 'tacitly accepted' this principle. ${ }^{49}$

Macdonald describes the acceptance of the principle of composite sentencing by the Court of Appeal as 'tacit' because, as he points out, it does not appear to be consistent with the House of Lords ruling in McCann that the original application for an ASBO under Section 1(1) CDA is a civil proceeding. The principle of composite sentencing allows the (criminal) court imposing sentence for breach to take into account the findings of the (civil) court which imposed the ASBO in determining the sentence, and that creates potential conflicts with Article 5 ECHR. ${ }^{50}$ Macdonald therefore argues that the theory requires that McCann be reversed and 'proceedings for the imposition of an ASBO be reclassified as criminal in nature so that findings of fact from these proceedings may be taken into account if and when any sentence for breach of the Order is subsequently imposed'. 51

The composite offence theory is not only at odds with the decision in McCann, but also with the reasons for that decision. The composite offence theory assumes that proceedings for breach of ASBO are not substantively independent of application proceedings and that since the breach proceedings result in punishment so too must application proceedings. 52 This was a line of argument pursued by the appellants in McCann, and the House of Lords rejected it, unanimously and emphatically. ${ }^{53}$ For the House of Lords, if the application proceedings serve their purpose, there will be no later breach proceedings with which to connect them. ${ }^{54}$ The earlier proceedings are therefore independent of the later set of proceedings. Only if the application proceedings do not serve their

\footnotetext{
48 See, Labour Party, n 12 above, 6. Macdonald also relies on two other sources of authority: first, a statement in Standing Committee by the Home Office Minister Alun Michael that the high maximum sentence for breach was necessary because breach of an ASBO involves 'a pattern of behaviour that is damaging people's lives over a considerable period of time' (cited in S. Macdonald 'The Nature of the ASBO' (2003) 66(4) Modern Law Review 633, n 6); Macdonald's second authority is Home Office guidance which states that ' $\mathrm{t}$ ] he sentence should be proportionate and reflect the impact of the behaviour complained of (Home Office, A Guide To Anti-Social Behaviour Orders (UK: Home Office, 2002), 48). But in itself, this does not specify whether the behaviour complained of includes the behaviour prior to imposition of the ASBO or only that in breach of it. Moreover, if it is the latter, the impact of the behaviour complained of in terms of the harassment, alarm or distress caused will be proportional to the threat the defendant continues to represent.

${ }^{49}$ Macdonald, n 46 above, 801.

50 ibid, 795 .

51 ibid, 805

52 This has been a core proposition of the ASBO's critics from the beginning. See, Ashworth, et al, 'Neighbouring on the Oppressive: The Government's “Anti-Social Behaviour Order" Proposals' (1998) 16(1) Criminal Justice 7.

53 R (McCann and Others) v Crown Court at Manchester and Another [2003] 1 AC 787, Lord Steyn at [808], Lord Hope at [821], Lord Hutton at [830].

${ }^{54}$ Lord Steyn, ibid.
} 
purpose and fail to prevent further acts of ASB will a penalty be imposed. But this does not alter the purpose of the earlier proceedings, which is to identify whether or not there is a need for a preventive order and, if there is, the specific terms of the order which are needed.

Since the House of Lords has ruled that the two sets of proceedings are independent, then sentencing for any breach of an ASBO, as a question of positive law, cannot be based on the aggregate impact of the entire course of conduct. And this is exactly how the Court of Appeal interpreted the position in Braxton when it disapproved of the possibility that a sentencing judge might have handed down a severe sentence as a punishment for the conduct leading up to the imposition of the order as well as for the breaching conduct. ${ }^{55}$ As Macdonald recognises, whatever the interpretation put on Stevens, the Braxton approach would rule out composite sentencing. ${ }^{56}$

Moreover, Judge LJ's ruling in Stevens is not entirely consistent with the composite offence theory. If, as the theory implies, 'harassment, alarm or distress' is merely the common currency in which the effects of different minor offences can be aggregated for sentencing purposes, then Lord Justice Judge's description of breach of ASBO as 'a distinct offence in its own right' must be something of an exaggeration.

The composite offence theory gives a plausible account of some of the language used in Stevens, but it does this only at the cost of being unable to explain the broader ASBO scheme and flatly contradicting the House of Lords in McCann. Macdonald's theory is a normative critique of the law, that adopts the standpoint of some of the original policy proposals, rather than an account of the legal effect of the statute that parliament in fact enacted. ${ }^{57}$ Macdonald nevertheless makes the strong claim that "without composite sentencing it is impossible to justify punishing breach of an ASBO with a criminal sentence of such severity'. ${ }^{58}$ What Macdonald means when he says that the maximum sentence cannot be justified is that it cannot be justified in the normative terms that he prefers.

A composite offence may or may not be superior in various respects to the breach of ASBO offence. But it cannot provide an explanation of the actual law because the theory sets out from the assumptions of the normative critique of the ASBO's hybrid procedure, namely (notwithstanding the unambiguous rulings of the House of Lords and the Court of Appeal to the contrary) that the ASBO is imposed with the purpose of punishing the person made subject to it. As a result, the theory fails to take seriously what the positive law actually requires of the

\footnotetext{
${ }^{55}$ See, $\mathrm{n} 25$ above at [5]. See also, the language used by Kay LJ when justifying the maximum sentence in Harris, text at $\mathrm{n} 28$ above.

56 Macdonald, n 46 above, 795.

57 It should be noted that in A Quiet Life (Labour Party, n 12 above), the Community Safety Order was presented as one of three separate changes proposed. One of the others was a composite criminal offence. It is therefore not entirely clear that the composite offence theory would be consistent even with the original CSO proposal, let alone the eventual ASBO; certainly it is doubtful that 'the principle of composite sentencing was thus an integral feature of the ASBO's design' (Macdonald, n 46 above, 793).

${ }^{58}$ Macdonald, ibid.
} 
courts when they come to punish for breaching an order: that defendants convicted of breach of ASBO should be punished in proportion to the threat to the security of others made manifest by their breach, which is to say in proportion to the seriousness of their failure to address their insecurity-causing behaviour.

\section{CONCLUSION}

The public protection theory of the breach of ASBO offence does not suffer from the explanatory problems of Macdonald's composite offence theory. It is consistent with McCann in the sense that it does not deny the separate and preventive purpose of the application proceedings. References at sentencing to a defendant's conduct preceding the imposition of the ASBO can be read as establishing the risk which the particular defendant represents of the particular conduct concerned in the breach and from which parliament has determined that the public should be protected. The public protection theory can also account for the lower sentences for breach of purely preventive terms. The theory's rationale for sentencing decisions has been explicitly adopted by the Court of Appeal.

The public protection theory draws our attention to the ASBO's essence as an instrument of threat-assessment and risk-management in which criminal defendants at trial have already been differentiated from ordinary citizens by the very charge that they face before any decision has been made as to whether they are guilty of the offence charged. This theory of breach of ASBO sentencing carries the threat-control rationale for imposing the ASBO forward into the sentence for breach. Where at the stage of imposing an ASBO, the law's putative wrong of manifesting a threatening disposition provides the occasion for a risk assessment and preventive response, ${ }^{59}$ at the second stage of punishing for breach of ASBO, the degree of risk made manifest by the defendant's continued failure to address this disposition is the basis upon which the seriousness of the criminal wrong is assessed. Sentencing decisions are then highly contextual since the wrong committed by the defendant is proportional to the degree of risk manifest in the breach, and this can only be calculated by reference to the defendant's particular pattern of behaviour and attitudes, and the reasons for imposing the ASBO in the first place. Even if the public protection theory successfully explains the law of breach of ASBO, it does not resolve a number of other problems with the offence.

While consistent with McCann, the theory does not necessarily resolve the potential difficulties, identified by Macdonald, that sentencing for breach of ASBO might still have with Article 5 ECHR. Although the defendant is not directly punished for the entire course of conduct and therefore for actions proved in a civil court (as she would be under the composite sentencing regime), the risk

59 See, Ramsay, n 32 above. 
assessment of the civil court still provides a significant background to the criminal sentence, in so far as any actual sentence takes into account the need for the specific deterrence of the particular defendant identified as a threat by the civil court. On the other hand, some sympathisers with the idea of composite sentencing identify the failure to punish at the breach stage for composite offences as a key practical weakness of the ASBO. ${ }^{60}$

In so far as the public protection theory suggests that the sentence is based on the incapacitation for public protection purposes of persons identified as a special risk, it directly raises all the normative and criminological question marks over such a heavy-handed penal response. ${ }^{61}$ Clinical predictions of future offending are notoriously unreliable. While the overall crime reduction effects of incapacitatory sentences are highly questionable, it cannot be doubted that they will do injustice in retributive terms. This has led many to conclude that sentencing on the grounds of the need for public protection from dangerous offenders lacks justification. Andrew Ashworth concludes a critique in these terms of the indeterminate sentencing provisions in the Criminal Justice Act 2003 by asking:

Is this critique unduly rationalist? One conception of public protection, we must recall, is a subjective feeling of security. The Government might argue that its aim is to create such feelings in members of the public. But is it justifiable to pursue policies aimed at fostering such feelings or aimed at increasing "public confidence" (a nebulous notion, at best), when it is known that such policies are unlikely to have a significant effect on objective risk or protection?62

We have seen that lying at the heart of the breach of ASBO sentencing case law is just such a division between the doing of 'objective' harms to interests, which is the focus of most stand-alone criminal offences, and representing a threat to 'subjective' feelings by manifesting a disposition to cause harassment, alarm or distress, which is punished by breach of ASBO. Section $1 \mathrm{CDA}$ constructs the continuing manifestation of the threat as a public wrong appropriate for punishment.

Three questions of particular interest are raised by this putative wrong against public confidence, questions that take us beyond the scope of this paper. The first is that, since the wrong done by a breach is proportionate to the threat made manifest, a court's sentence will be proportionate to the wrong done in the ordinary sense of proportionality and, at the same time, proportionate to the risk of future wrongful behaviour. Sentencing appears to achieve a union of retributive

\footnotetext{
${ }^{60}$ Hansen, Bill, and Pease, $\mathrm{n} 46$ above.

61 See, A. Ashworth, 'Criminal Justice Act 2003: Part 2: Criminal Justice Reform-Principles, Human Rights and Public Protection' (2004) Criminal Law Review 517; A. Ashworth, Sentencing and Criminal Justice (Cambridge: Cambridge University Press, 2005) ch 6.

62 Ashworth, ibid, 531.
} 
and public protection rationales for punishment. But whether this is right depends on the answer to the second question: are parliament and the courts right that this continuing manifestation of a threatening disposition is a wrong, and, more particularly, that it is a wrong that is deserving of state punishment?

In addition to this normative question, there is a third explanatory question about where this sense of a public wrong has come from. Distinguishing the wrong of continuing to be a threat of harassment, alarm or distress in defiance of an ASBO from the wrongs prohibited by stand-alone criminal offences leads to the interesting conclusion that the harassment, alarm or distress caused by the sexual offending of a defendant like Harris is to be regarded as a problem at least as serious and wrongful as the actual sex offences. And yet what must, therefore, be a fairly serious wrong could not have been punished in anything like this way until a decade ago. ${ }^{63}$ How is it that a wrong that is so serious as to justify a near doubling of Harris' total sentence or a two-thirds increase in Lawson's was either not recognised or could not have been punished before the late 1990s? Why has an individual's failure to respond to an official assessment of the threat they represent only recently come to be regarded as such a serious criminal wrong by parliament and the courts? ${ }^{64}$

\footnotetext{
${ }^{63}$ Intentionally causing harassment, alarm or distress contrary to Public Order Act 1986, s 4A carries a maximum of six months in prison.

${ }^{64}$ I have argued elsewhere that the substantive liability to the ASBO appears to be premised on a crisis of sovereign authority that is officially promoted, see, Vulnerability, Sovereignty and Police Power in the ASBO' in M Dubber and M Valverde (eds), Police and the Liberal State (Stanford: Stanford University Press, 2008).
} 